\title{
Nutritive Quality of Thampala (Amaranthus spp.) as a Forage Crop in Sri Lanka
}

\author{
I.K. Leukebandara ${ }^{*}$, S. Premaratne ${ }^{1}$ and B.L. Peiris ${ }^{2}$ \\ Postgraduate Institute of Agriculture \\ University of Peradeniya \\ Sri Lanka
}

\begin{abstract}
Forage quality characteristics of amaranth (Amaranthus spp.) have not been studied so far in Sri Lanka. Therefore, this study was carried out to compare the forage nutritional value of five different amaranth cultivars namely, Amaranthus hybridus, Amaranthus caudatus, Amaranthus hypochondriacus, Amaranthus cruentus, Amaranthus dubious together with Guinea 'A' grass (Panicum maximum), cowpea (Vigna unguiculata) and maize ( $\underline{\text { Zea }} \underline{\text { mays }}$ ), at three different harvesting times, namely early bloom, mid bloom and late bloom stages of the crop. A randomized complete block design (RCBD) with three replicates was used to compare eight treatments (five amaranth species, guinea grass, cowpea and maize). Seeds of eight plant species were randomly established in eight plots of each block separately and proximate composition was analyzed. In all three harvests, dry matter (DM) content in amaranth was ranged from 7.43-17.77\% in contrast to the 14.67$17.77 \%, 13.43-19.10 \%$ and 13.17-18.27\% in cowpea, Guinea grass and maize respectively. At all three harvests, higher amounts of crude protein $(C P)$ were found in amaranth compared to other three forages studied. Amaranth contains approximately one and half to two times more $C P$ than Guinea grass at 50 days after planting while it was one and half times more $C P$ than Guinea grass in 80 days after planting. In addition to the above, CP content in all plant species have been decreased with the maturity of plants. Crude fiber (CF) content observed in cowpea, Guinea grass and maize was 21.77-33.67\%, 28.00-36.57\% and 22.40-25.70\% respectively, while it was 9.43-24.50\% in amaranth. Ether extract (EE) content observed in amaranth was ranged from 2.37-3.60\% in contrast to cowpea (4.03$5.67 \%)$, Guinea grass (1.60-2.40\%) and maize (2.43-2.47\%). Ash content in Amaranthus 3.60) spp. was ranged from 11.43-21.53\%. Revealed results conclude that amaranth could be developed as a high quality forage crop in Sri Lanka.
\end{abstract}

Keywords: Forage quality, proximate composition, Thampala (Amaranth)

\section{INTRODUCTION}

Amaranth (Amaranthus spp.) is a dicotyledonous plant which is widely grown for human consumption in Sri Lanka and in many other tropical countries. Many wild relatives of this plant are found everywhere in home gardens, road sides and bare lands while being freely available as a natural forage for grazing animals and other livestock in Sri Lanka.

\footnotetext{
Department of Animal Science, Faculty of Agriculture, University of Peradeniya, Sri Lanka

2 Department of Crop Science, Faculty of Agriculture, University of Peradeniya, Sri Lanka

Corresponding author: ikleukebandara@live.com
} 
Amaranth is a plant with $\mathrm{C}_{4}$ metabolism (Gimplinger et al., 2007) and belongs to the family Amaranthaceae, and genus Amaranthus. It is one of the few non grasses with potential of becoming a cereal like grain crop (National Research Council., 1984). It is also known as a pseudo cereal. Different types of Amaranth species are cultivated in most tropical regions of the world for its vegetable protein for human consumption (Fasuyi et al., 2008). According to Svirskis (2003), Amaranth is a forage plant characterized by a more effective photosynthesis, more intensive nitrogen metabolism, and a good adaptability. It is a fast growing hardy plant and it has a wide geographic and environmental adaptability. It is also an important grain or vegetable crop in India, Pakistan, Nepal, China and several other countries (Robinson, 1986; Stahlknecht and Schulz-Schaeffer, 1993). Rapid growth, efficient water utilization and high protein content in the green mass of this plant make it a suitable crop for animal feeding (Pospisil and Pospisil, 2008).

In Sri Lanka, potential of Amaranth species as a forage crop has not been studied and Amaranth is not being grown and utilized as a forage crop so far. According to Rezai et al., (2009), nutritive value of Amaranth as a forage is similar to the commonly used forage and has an excellent forage quality at certain stages of development. Therefore, this study was carried out to compare the forage nutritive value of 05 Amaranth cultivars, namely, $A$. hybridus, A. caudatus, A. hypochondriacus, A. cruentus, A. dubious together with other forage namely, Guinea 'A' grass (Panicum maximum), Cowpea (Vigna unguiculata) and Maize (Zea mays) in Sri Lanka.

\section{METHODOLOGY}

The study was carried out at the experimental field of Veterinary Research Institute at Gannoruwa in Mid Country Wet Zone (mean annual temperature $24.3{ }^{\circ} \mathrm{C}$; annual average humidity $82.7 \%$; annual total precipitation $1917.20 \mathrm{~mm}$; and the altitude $480 \mathrm{~m}$ ). The soil type of the experimental field was sandy loam. The experimental design was a randomized complete block design (RCBD) with three replicates. Seeds were used as planting material and spacing at $0.60 \times 0.45 \mathrm{~m}$ was given for all the varieties. After 10-14 days of seeds establishment, thinning out of seedlings were carried out to get the above mentioned plant spacing.

First harvesting/sampling of the different plant varieties was done at 50 days after planting (50 dap) (early bloom) and subsequent two harvestings were repeated at 80 days (80 dap) (mid-bloom) and 110 days after planting (110 dap) (late bloom), selecting randomly the middle portion of the plot. Three sub samples were obtained for nutritive quality analysis.

Experimental plants were cut harvested (approximately 500-600 g), at the height of $15 \mathrm{~cm}$ from the ground level, at the first harvesting and, at the subsequent harvestings $30-40 \mathrm{~cm}$ long branches (same sample size) were cut harvested. Fresh weights of each sample were recorded and chopped into $0.5-4.0 \mathrm{~cm}$ pieces, obtained three samples from each plot, dried at $60{ }^{\circ} \mathrm{C}$ for dry matter determination. Samples were ground to pass a $1 \mathrm{~mm}$ sieve and analyzed for proximate composition using standard methods (AOAC, 1990).

The general linear model (GLM) procedure of SAS was used to analyze the data (SAS, 2009) and mean comparisons were done by the least significant difference (LSD). 


\section{RESULTS AND DISCUSSION}

\section{Dry matter (DM)}

At the first harvest, the highest $(\mathrm{p}<0.05)$ DM content was recorded in Cow pea and the lowest $(\mathrm{p}<0.05)$ value was recorded in A. cruentus (Table 1$)$. In the second harvest, the highest $(\mathrm{p}<0.05)$ DM content of $18.27 \%$ was recorded in Maize and the lowest $(\mathrm{p}<0.05)$ value of $11.87 \%$ was recorded in A. hybridus. At the third harvest, the highest $(\mathrm{p}<0.05) \mathrm{DM}$ content was recorded in Guinea grass and the lowest $(\mathrm{P}<0.05)$ value was recorded in $A$. hypochondriacus. According to literature, the DM content in Cowpea, Guinea grass and Maize were $20.9 \%$ (Feedipedia, 2012), 26\% (Odedire and Babayemi, 2008) and 32.7\% (Olorunnisomo, 2010), respectively. Dry matter values observed in the present study were lower than the values reported by the previous authors. These differences may be due to growth stage differences of the above mentioned plant species at the time of harvesting in the different studies.

Table 1. Dry matter (DM) content in different plant species at different harvesting times, $\%^{\dagger}$

\begin{tabular}{|c|c|c|c|}
\hline \multirow{2}{*}{ Plant species } & \multicolumn{3}{|c|}{ Harvest } \\
\hline & 50 dap & 80 dap & 110 dap \\
\hline A. hybridus & $8.60( \pm 0.70)^{b}$ & $11.87( \pm 1.47)^{\mathrm{c}}$ & $16.33( \pm 0.83)^{\mathrm{ab}}$ \\
\hline A. caudatus & $8.57( \pm 1.71)^{b}$ & $13.43( \pm 1.52)^{\mathrm{bc}}$ & $15.43( \pm 1.79)^{\mathrm{b}}$ \\
\hline A. hypochondriacus & $8.73( \pm 0.73)^{b}$ & $13.20( \pm 1.17)^{\mathrm{bc}}$ & $15.40( \pm 0.96)^{b}$ \\
\hline A.cruentus & $7.43( \pm 0.88)^{b}$ & $13.87( \pm 2.14)^{\mathrm{bc}}$ & $17.77( \pm 1.24)^{\mathrm{ab}}$ \\
\hline A. dubious & $8.03( \pm 1.18)^{\mathrm{b}}$ & $14.33( \pm 2.20)^{\mathrm{bc}}$ & $16.63( \pm 2.47)^{\mathrm{ab}}$ \\
\hline Cowpea $^{\$}$ & $14.67( \pm 0.28)^{\mathrm{a}}$ & $17.77( \pm 2.57)^{\mathrm{a}}$ & - \\
\hline Guinea 'A' grass & $13.43( \pm 2.02)^{\mathrm{a}}$ & $16.27( \pm 1.19)^{\mathrm{ab}}$ & $19.10( \pm 0.25)^{\mathrm{a}}$ \\
\hline Maize $^{\$}$ & $13.17( \pm 2.42)^{\mathrm{a}}$ & $18.27( \pm 2.28)^{\mathrm{a}}$ & - \\
\hline
\end{tabular}

As reported by Ibrahim in 1988, dry matter content in aerial parts of Cowpea is $11.1 \%$. This value is close to the DM content observed in the first harvest of the present study. The DM content of Guinea observed in the third harvest of the present study (19.1\%), was close to the DM content of $20 \%$ (with cattle manure) in Guinea grass (Guinea cv VRI-435) (Ibrahim, 1988).

\section{Crude protein $(\mathbf{C P})$}

At 50 dap, the highest $\mathrm{CP}(\mathrm{p}<0.05)$ content $(25.73 \%)$ was recorded in A. hypochondriacus and the lowest $(\mathrm{p}<0.05) \mathrm{CP}$ content $(12.8 \%)$ was recorded in Maize (Table 2). These values are in agreement with the $\mathrm{CP}$ values reported by Whitehead et al. in 2001 in Amaranth plants harvested approximately 40 days after germination (24.0-26.7\%). At the 80 dap, the highest CP content $(\mathrm{p}<0.05)$ was recorded in A. hybridus and the lowest $(\mathrm{p}<0.05)$ CP content was recorded in Maize as observed previously. In the third harvest, the highest $(\mathrm{p}<0.05) \mathrm{CP}$ content of $14.30 \%$ was recorded in A. hybridus and the lowest $(\mathrm{p}<0.05)$ value of $8.67 \%$ was recorded in Guinea 'A' grass. According to CP values reported by Stordahl et al., (1999), CP 
content of Amaranth at 8 weeks after planting was $23 \%$ and with maturity it has declined to $13 \%$.

However, CP values of Amaranth reported by Adeyeye and Omolayo in 2011 were relatively higher (33.70-35.90\%), in comparison to the $\mathrm{CP}$ values observed in the present investigation. This may be due to differences in growth stages of Amaranth, at harvesting in two different trials. According to Olorunnisomo in $2010 \mathrm{CP}$ content in Maize was 8-9\%. This value is close to the CP content in Maize observed in the second harvest of the present study $(8.13 \%)$ (Table 2). In the same harvest Amaranth contained nearly one and a half to two times more $\mathrm{CP}$ than Maize. In the first harvest, it's nearly two times more CP than Maize.

Crude Protein content in aerial parts of Cowpea was $18.1 \%$ on dry matter basis (Feedipedia, 2012), where as the average CP value of Cowpea observed in first and second harvests were $17.23 \%$ in the present study. In the first harvest CP values of all Amaranth species were higher than the $\mathrm{CP}$ value observed in Cowpea.

Table 2. Crude protein content (CP) in different plant species (DM basis), $\%{ }^{\dagger}$

\begin{tabular}{lccc}
\hline \multirow{2}{*}{ Plant species } & \multicolumn{3}{c}{ Harvest } \\
\cline { 2 - 4 } & 50 dap & 80 dap & 110 dap \\
\hline A. hybridus & $24.57( \pm 0.55)^{\mathrm{a}}$ & $18.67( \pm 0.03)^{\mathrm{a}}$ & $14.30( \pm 0.40)^{\mathrm{a}}$ \\
A. caudatus & $24.73( \pm 0.29)^{\mathrm{a}}$ & $14.30( \pm 1.55)^{\mathrm{ab}}$ & $14.23( \pm 0.43)^{\mathrm{a}}$ \\
A. hypochondriacus & $25.73( \pm 0.59)^{\mathrm{a}}$ & $18.43( \pm 1.49)^{\mathrm{ab}}$ & $13.73( \pm 1.10)^{\mathrm{a}}$ \\
A.cruentus $_{\text {A. dubious }}^{\mathrm{a}}$ & $22.70( \pm 1.39)^{\mathrm{ab}}$ & $16.00( \pm 0.75)^{\mathrm{ab}}$ & $13.43( \pm 0.43)^{\mathrm{a}}$ \\
Cowpea $^{\$}$ & $23.60( \pm 0.61)^{\mathrm{ab}}$ & $14.97( \pm 1.60)^{\mathrm{ab}}$ & $12.97( \pm 1.13)^{\mathrm{a}}$ \\
Guinea 'A'grass $^{\text {'Aaize }}$ & $21.03( \pm 2.72)^{\mathrm{b}}$ & $13.43( \pm 0.92)^{\mathrm{b}}$ & - \\
M $^{\mathrm{b}}$ & $17.47( \pm 1.35)^{\mathrm{c}}$ & $13.57( \pm 3.38)^{\mathrm{b}}$ & $8.67( \pm 0.55)^{\mathrm{b}}$ \\
\hline
\end{tabular}

${ }^{\dagger}$ Average of $3 \times 3$ samples. Mean \pm SE

Means with different superscripts in columns are significantly different $(\mathrm{p}<0.05)$.

${ }^{\$}$ As life span is over, Cowpea and Maize samples were not collected at 110 dap

As reported by Odedire and Babayemi in 2008, Guinea grass had a CP content of $9.36 \%$ and this value is close to the $8.67 \%$ of $\mathrm{CP}$ in forage Guinea grass observed in the third harvest of the present investigation. However, CP content of Guinea 'A' grass at the first harvest of the present study (17.47\%) was similar to the CP value (17.7\%) observed by Ibrahim in 1988, at the stage of one week after flowering of Guinea grass. Amaranth contains approximately one and half to two times more $\mathrm{CP}$ than Guinea grass in the first harvest. While it was approximately one and half times more CP than Guinea grass in the second harvest. As observed in the Table 2, at all three harvestings, higher amounts of CP were found in Amaranth compared to other three forage studied in the trial. In addition to the above, CP content in all plant species have been decreased with the maturity of plants.

\section{Crude fiber (CF)}

As observed in the first harvest, the highest $(\mathrm{p}<0.05)$ CF content of $28 \%$ was recorded in Guinea grass and the lowest $(\mathrm{p}<0.05)$ value of $9.43 \%$ was recorded in A. hypochondriacus (Table 3). The CF content between Cowpea, Guinea grass and Maize were not different $(p>0.05)$ from each other. Similarly in the second harvest, the highest $(p<0.05)$ CF content of $36 \%$ was recorded in Guinea ' $\mathrm{A}$ ' grass and the lowest $(\mathrm{P}<0.05)$ value of $18.83 \%$ was recorded in A. dubious. In the third harvest, as observed in previous harvests, the highest 
$(\mathrm{P}<0.05) \mathrm{CF}$ content of $36.57 \%$ was recorded in Guinea 'A' grass and the lowest $(\mathrm{p}<0.05)$ value of $19.87 \%$ was recorded in A. hybridus.

Table 3. Crude fiber (CF) content in different plant species (DM basis) at different harvesting dates, $\%{ }^{\dagger}$

\begin{tabular}{lccc}
\hline & \multicolumn{3}{c}{ Harvest } \\
\cline { 2 - 4 } Plant species & $\mathbf{5 0}$ dap & $\mathbf{8 0}$ dap & $\mathbf{1 1 0}$ dap \\
\hline A. hybridus & $10.33( \pm 1.11)^{\mathrm{c}}$ & $19.03( \pm 1.91)^{\mathrm{d}}$ & $19.87( \pm 2.51)^{\mathrm{b}}$ \\
A. caudatus & $11.27( \pm 0.63)^{\mathrm{c}}$ & $21.80( \pm 1.36)^{\mathrm{dc}}$ & $21.63( \pm 0.69)^{\mathrm{b}}$ \\
A. hypochondriacus & $9.43( \pm 0.69)^{\mathrm{c}}$ & $24.50( \pm 2.24)^{\mathrm{bc}}$ & $23.47( \pm 1.39)^{\mathrm{b}}$ \\
A.cruentus & $12.93( \pm 1.99)^{\mathrm{bc}}$ & $24.50( \pm 3.43)^{\mathrm{bc}}$ & $20.17( \pm 0.81)^{\mathrm{b}}$ \\
A. dubious & $10.80( \pm 1.10)^{\mathrm{c}}$ & $18.83( \pm 3.47)^{\mathrm{d}}$ & $20.43( \pm 1.65)^{\mathrm{b}}$ \\
Cowpea $^{\$}$ & $21.77( \pm 3.63)^{\mathrm{ab}}$ & $33.67( \pm 2.66)^{\mathrm{a}}$ & - \\
Guinea grass $^{\mathrm{a}}$ & $28.00( \pm 2.10)^{\mathrm{a}}$ & $36.00( \pm 1.61)^{\mathrm{a}}$ & $36.57( \pm 0.70)^{\mathrm{a}}$ \\
Maize $^{\$}$ & $22.40( \pm 6.63)^{\mathrm{ab}}$ & $25.70( \pm 0.86)^{\mathrm{b}}$ & - \\
\hline
\end{tabular}

Average of $3 \times 3$ samples, Mean \pm SE

Means with different superscripts in columns are significantly different $(\mathrm{p}<0.05)$

${ }^{\$}$ As life span is over, Cowpea and Maize samples were not collected at 110 dap

Crude Fiber content in aerial parts of Cowpea reported by Ibrahim in 1988 was $24.3 \%$, compared to the $\mathrm{CF}$ content of $21.77 \%$ observed by the present investigation whereas, $\mathrm{CF}$ content of Guinea grass observed in the present study was similar to the CF values of Guinea CV. VRI-435 (33.5-39.0\%) as observed by Ibrahim in 1988. A relatively low range of CF values of Amaranth (1.55-1.85\%) were reported by Adeyeye and Omolayo in 2011, compared to the present study. These differences in their results could be due to the reason that collection of samples from immature plants, most probably before the flowering stage ((Table 3).

\section{Ether extract (EE)}

At the first harvest, the highest $(p<0.05)$ EE content of $5.67 \%$ was recorded in Cowpea and the lowest $(p<0.05)$ value of $2.40 \%$ was recorded in Guinea grass (Table 4). At the third harvest, the highest $(\mathrm{p}<0.05)$ EE content of $3.17 \%$ was recorded in A.cruentus and the lowest $(\mathrm{p}<0.05)$ value of $1.60 \%$ was recorded in Guinea grass. These values were less than the EE values reported by Adeyeye and Omolayo in 2011, (9.58-9.62\%). High EE values observed in this study compared to the relatively low values of EE in the present study could be due to the reason that differences in maturity levels in experimental plants, at the time of collection of samples. 
Table 4. Ether Extract (EE) content in different plant species (DM basis) at different harvest dates, $\%$

\begin{tabular}{llcc}
\hline \multirow{2}{*}{ Plant species } & \multicolumn{3}{c}{ Harvest } \\
\cline { 2 - 4 } & First $(\mathbf{5 0}$ dap) & Second $(80$ dap) & Third(110 dap) \\
\hline A. hybridus & $3.17( \pm 0.18)^{\mathrm{b}}$ & $2.50( \pm 0.25)^{\mathrm{a}}$ & $3.13( \pm 0.09)^{\mathrm{a}}$ \\
A. caudatus & $2.70( \pm 0.10)^{\mathrm{b}}$ & $2.90( \pm 0.50)^{\mathrm{ab}}$ & $3.03( \pm 0.38)^{\mathrm{a}}$ \\
A. hypochondriacus & $3.10( \pm 0.32)^{\mathrm{b}}$ & $3.17( \pm 1.07)^{\mathrm{ab}}$ & $3.03( \pm 0.49)^{\mathrm{a}}$ \\
A. cruentus & $2.70( \pm 0.32)^{\mathrm{b}}$ & $3.60( \pm 0.31)^{\mathrm{ab}}$ & $3.17( \pm 0.23)^{\mathrm{a}}$ \\
A. dubious $_{\text {Cowpea }}$ & $3.20( \pm 0.31)^{\mathrm{b}}$ & $2.97( \pm 0.78)^{\mathrm{ab}}$ & $2.37( \pm 0.09)^{\mathrm{ab}}$ \\
Guinea 'A'grass $^{\mathrm{b}}$ & $5.67( \pm 1.66)^{\mathrm{a}}$ & $4.03( \pm 0.33)^{\mathrm{a}}$ & - \\
Maize $^{\$}$ & $2.40( \pm 0.38)^{\mathrm{b}}$ & $2.20( \pm 0.17)^{\mathrm{b}}$ & $1.60( \pm 0.15)^{\mathrm{b}}$ \\
\hline
\end{tabular}

${ }^{\dagger}$ Average of $3 \times 3$ samples, Mean \pm SE

Means with different superscripts in columns are significantly different $(\mathrm{p}<0.05)$.

${ }^{\$}$ As life span is over, cowpea and maize samples were not collected at 110 dap

\section{Ash}

At the first and the second harvests, the highest $(\mathrm{p}<0.05)$ ash content was recorded in $A$. hybridus and the lowest $(\mathrm{p}<0.05)$ value was recorded in Maize (Table 5). At the third harvest, the highest $(\mathrm{p}<0.05)$ ash content of $13.73 \%$ was recorded in A. cruentus and the lowest $(\mathrm{p}<0.05)$ value of $7.47 \%$ was recorded in Guinea ' $A$ ' grass.

Ash content of most of the Amaranth species in the second harvest (80 dap), of the present study (15.33-17.87\%), is approximately similar to the values reported by Adeyeye and Omolayo in 2011(17.19-17.21\%). Ash content in vegetative parts of Maize, reported by Olorunnisomo in 2010 was $4.58 \%$ and this value is close to the ash content of Maize observed in the second harvest of the present study (5.07\%). Considering all three harvests,

Table 5. Ash contents in different plant species (DM basis), at different harvesting dates, $\%^{\dagger}$

\begin{tabular}{|c|c|c|c|}
\hline \multirow{2}{*}{ Plant species } & \multicolumn{3}{|c|}{ Harvest } \\
\hline & First (50 dap) & $\operatorname{Second}(80$ dap $)$ & Third(110dap \\
\hline A. hybridus & $21.53( \pm 0.83)^{\mathrm{a}}$ & $17.87( \pm 1.46)^{\mathrm{a}}$ & $13.40( \pm 0.76)^{\mathrm{a}}$ \\
\hline A. caudatus & $20.33( \pm 1.05)^{\mathrm{a}}$ & $13.60( \pm 1.54)^{\mathrm{b}}$ & $11.43( \pm 1.75)^{\mathrm{ab}}$ \\
\hline A. hypochondriacus & $21.50( \pm 1.80)^{\mathrm{a}}$ & $16.83( \pm 2.12)^{\mathrm{ab}}$ & $12.30( \pm 2.08)^{\mathrm{ab}}$ \\
\hline A.cruentus & $20.87( \pm 1.65)^{\mathrm{a}}$ & $15.33( \pm 2.14)^{\mathrm{ab}}$ & $13.73( \pm 1.97)^{\mathrm{a}}$ \\
\hline A. dubious & $19.30( \pm 2.89)^{\mathrm{a}}$ & $16.13( \pm 2.74)^{\mathrm{ab}}$ & $13.07( \pm 1.64)^{\mathrm{a}}$ \\
\hline Cowpea $^{\$}$ & $9.60( \pm 1.19)^{\mathrm{b}}$ & $8.17( \pm 0.64)^{\mathrm{cd}}$ & - \\
\hline Guinea 'A' grass & $11.57( \pm 2.01)^{\mathrm{b}}$ & $8.87( \pm 1.04)^{\mathrm{c}}$ & $7.47( \pm 0.48)^{\mathrm{b}}$ \\
\hline Maize & $9.20( \pm 1.39)^{\mathrm{b}}$ & $5.07( \pm 0.48)^{\mathrm{d}}$ & - \\
\hline
\end{tabular}


all Amaranth species at the first harvest contained approximately four times of ash than that of Maize in the first harvest. In the second harvest it was nearly three times and in the third harvest amaranth contained two times more ash than the Maize in the second harvest.

Aerial parts of Cowpea contained 11.30\% ash (DM basis), as reported in Feedipedia 2012. This value is close to the ash content of Cowpea reported in the present investigation $(9.6 \%$ DM basis at the first harvest). Considering the different harvests, Amaranth contained nearly two times more ash content than the Cowpea in the first harvest. In the second and third harvests, ash content of all Amaranth species is greater than that of Cowpea (Table 5).

As reported by Odedire and Babayemi in 2008, Guinea 'A' grass contained an ash content of $12.0 \%$. This value is close to the ash content observed in Guinea ' $A$ ' grass in the first harvest of the present study (Table 5). Considering the ash content, all Amaranth species are better than Guinea 'A' grass. In the first harvest, Amaranth contained nearly one and a half to two times more ash than the Guinea 'A' grass. While in the second and third harvests, ash content of all Amaranth species were higher than that of Guinea 'A' grass (Table 5).

\section{CONCLUSION}

High Crude protein and ash content in all Amaranth species in all three harvests, suggests that Amaranth may provide high quality forage for livestock in Sri Lanka. Forage quality parameters of Amaranth are similar or better than commonly used forages evaluated in this study. Therefore Amaranth would be a good alternative for the problem of inadequate supply of quality forage during the dry season. Therefore, introduction of this plant as a new forage crop for livestock production in Sri Lanka would be highly acceptable and beneficial, on the basis of nutritional significance and it would also make an opportunity for diversification of animal feeding systems.

However further studies are needed to evaluate economics of feeding Amaranth and to determine their nutritional excellence in different climatic zones in different farming systems of Sri Lanka. Determination of anti-nutritional factors in different Amaranth varieties in different growth stages is equally important to address the feed safety issues. Animal performance trials, digestibility and palatability studies with feeding Amaranth should also be conducted, to evaluate their potential, in different livestock species, in different farming systems of Sri Lanka.

\section{REFERENCES}

AOAC. (1990). Official Methods of Analysis, $16^{\text {th }}$ Edition, Association of Official Analytical Chemists, Washington, D.C. USA

Adeyeye, E.L. and Omolayo, F.O. (2011). Chemical Composition and Functional Properties of Leaf Protein Concentrates of Amaranthus hybridus and Telfairia occidentalis. Agriculture and Biology J.of North America. http://www.scihub.org/ABJNA

Fasuyi, A.O., Dairo, F.A.S. and Adeniji, A.O. (2008). Tropical Vegetable (Amaranthus cruentus) Leaf Meal as Alternative Protein Supplement in Broiler Starter Diets: Bio Nutritional Evaluation 9 (1), 23 - 34 
Feedipedia. (2012). Animal Feed Resources Information System- INRA CIRAD AFZ and FAO 2012-2013. http//:www.feedpedia.org/node/12025

Gimplinger, D.M., Dobos, G., Schonlechner R. and Kaul, H.P. (2007). Yield and Quality of Grain Amaranth (Amaranthus sp.) in Eastern Austria. Plant Soil Environ. 53(3), 105 - 112

Ibrahim, M.N.M. (1988). Feeding Tables for Ruminants in Sri Lanka, Fibrous Feed Utilization Project. Sri Lanka-Netherlands Livestock Development Program, Kandy Offset Printers Ltd., Kandy, Sri Lanka

National Research Council. (1984). Amaranth: Modern Prospects for an ancient Crop. Washington, D.C: National Academy Press, 1984.

Odedire, J.A. and Babayemi, O.J. (2008). Comparative Studies on the Yield and Chemical Composition of Panicum maximum and Andropogon gayanus as influenced by Tephrosia candida and Leucaena leucocephala. Livestock Research for Rural Development, 20(2).

Olorunnisomo, O.A. (2010). Nutritive Value of Conserved Maize, Amaranth or MaizeAmaranth Mixture as Dry Season Fodder for Growing West African Dwarf Sheep. Livestock Research for Rural Development. 22(10):2010. http://www.Irrd.org/Irrd22/10/olor22191.htm

Pospisil, A. and Pospisil, M. (2008). Green Mass and Dry Matter Yield, and Nutritional Value of Forage Sorghum and Amaranth at Different Growth Stages. Bulletin UASVM, Agriculture 65(1), $1843-5386$

Rezaei, J., Rouzbehan, Y., and Fazaeli, H., (2009). Nutritive Value of Fresh and Ensiled Amaranth (Amaranthus hypochondriacus) Treated with Different Levels of Molasses. Animal feed Science and Technology, 15(12), 153 - 160

Robinson, R.G. (1986). Amaranth, Quinoa, Ragi, Tef and Niger: Tiny seeds of Ancient History and Modern Interest. Minnesota Agric. Exp.Stn.Bull, AD-SB-2949

SAS. (2009). SAS/STAT User's Guide. Version 6.12, SAS Institute Inc., Cary, North Carolina, USA.

Stahlknecht, G.F. and Schulz-Schaeffer, J.R. (1993). Amaranth Rediscovered. p.211-218. In: J. Janick and J.E.Simon (eds.). New crops. Wiley, New York.

Stordahl, J.L., Sheaffer, C.C., DiCostanzo, A. (1999). Variety and maturity affect amaranth forage yield and quality. Journal of Production Agriculture, 12, 249-253

Svirskis, A. (2003). Investigation of Amaranth Cultivation and Utilization in Lithuania. Agro.Res. 1(2), 253 - 264.

Whitehead, W.F., Terrill, T.H., Singh. B.P. and Galaye, S. (2001). Amaranth Productivity and Nutrient Composition in Central Georgia. Proc. XIX International Grassland Congress, Feb. 2001. Piracicaba, Brazil 